Article

\title{
Variations of Heavy Metals from Geothermal Spring to Surrounding Soil and Mangifera Indica-Siloam Village, Limpopo Province
}

\author{
Olatunde S. Durowoju ${ }^{1, *}$, John O. Odiyo ${ }^{1}$ and Georges-Ivo E. Ekosse ${ }^{2}$ \\ Received: 22 November 2015; Accepted: 6 January 2016; Published: 14 January 2016 \\ Academic Editor: Vincenzo Torretta \\ 1 Department of Hydrology and Water Resources, University of Venda, Private Bag X5050, \\ Thohoyandou 0950, South Africa; john.odiyo@univen.ac.za \\ 2 Directorate of Research and Innovation, University of Venda, Private Bag X5050, \\ Thohoyandou 0950, South Africa; Georges-Ivo.Ekosse@univen.ac.za \\ * Correspondence: durotunde@gmail.com; Tel.: +27-780-642-299
}

\begin{abstract}
Assessment of seasonal variation in concentration of heavy metals- $\mathrm{As}, \mathrm{Cd}, \mathrm{Co}, \mathrm{Cr}, \mathrm{Cu}, \mathrm{Ni}$, $\mathrm{Pb}$, and $\mathrm{Zn}$ from the Siloam Geothermal Spring and their impacts on surface soils and Mangifera indica were undertaken during winter and summer seasons in South Africa. This was done to determine the environmental pollution status of surface soils and Mangifera indica around the geothermal spring. The geothermal spring water, surface soil $(0-15 \mathrm{~cm})$ and Mangifera indica (bark and leaves) samples were collected during 2014 winter and summer seasons. Soil and Mangifera indica samples were treated and digested using microwave and block digestion methods, respectively. The heavy metal concentrations were determined with inductively coupled plasma-mass spectrometer (ICP-MS) (Agilent 7700). The result from this study showed that levels of heavy metals were higher in summer compared to winter season for geothermal spring water, surface soil, and Mangifera indica (barks and leaves). In two-tailed tests (Mann-Whitney U-test), geothermal spring water alone showed significant differences $(Z=-2.1035, p<0.05)$, whereas the surface soil and barks and leaves of Mangifera indica showed no significant differences $(Z=0.053 ; 0 ;-0.524, p>0.05)$ in both seasons. Some heavy metals concentrations were above the standard guidelines for drinking water and typical soil, making the soil contaminated. This is a cause for concern as it can affect the environment and the health of the inhabitants of Siloam village, who depend on the geothermal spring as their source of domestic water, irrigation, and other uses. This study also showed that Mangifera indica has a phytoremediative property, which lessens the heavy metal concentrations absorbed from the contaminated soil.
\end{abstract}

Keywords: environmental pollution; geothermal spring; heavy metals; Mangifera indica; phytoremediative property; surface soil

\section{Introduction}

Heavy metals pollution has become a serious environmental problem. However, the investigation of heavy metals from the geothermal spring to the surface soil and vegetation is essential since geothermal spring is rich in elements owing to the rock-water interaction in the deep aquifer [1]. The situation is even more worrisome particularly in South Africa where geothermal springs are under-researched and under-utilized [2]. However, geothermal resources are gaining recognition of value even in South Africa as predicted by Olivier et al. [2].

Siloam geothermal spring is regarded as scalding spring [3] and the hottest spring in South Africa with average temperatures of $62^{\circ} \mathrm{C}-67.5^{\circ} \mathrm{C}$ [2]. The temperature of geothermal springs is influenced by the temperature of the magma (for volcanic springs), the depth of penetration, and the nature 
of conduits of water to the surface [4]. The faster the water comes to the surface, the less chance it has to cool down and thus the hotter it is [4,5]. A study by Odiyo and Makungo [6] reported that geochemical dissolution of the rock increases with temperature. A number of studies have found that geothermal spring water may contain toxic elements such as arsenic, cadmium, chromium, selenium, and mercury [7-9] for which contamination is a major environmental concern due to their toxicity, carcinogenicity, and mutagenicity even at low concentration [10]. The use of geothermal spring water for domestic and agricultural purposes is prevalent in Siloam village.

Several researchers generally define "heavy metal" as a collective term, which applies to category of metals and metalloids with atomic density greater than $4 \mathrm{~g} / \mathrm{cm}^{3}$ or five times or more, greater than water [11-16]. Heavy metals are found generally at trace levels in soil and vegetation, and living organisms need micro-quantity of some metals for their metabolism. However, these have toxic effects on the organisms at high concentrations. Gune et al. [17] outlined that heavy metal toxicity has an inhibitory effect on plant growth, enzymatic activity, stomata function, photosynthesis activity and accumulation of other nutrient elements as well as damages to the root system.

Rural communities such as at Siloam village produce most of their food on the land on which they live. When agricultural soils are contaminated, these heavy metals are taken up by surrounding vegetation and consequently accumulate in their tissues [18]. To a small extent heavy metals enter the body through food, air, and water and bio-accumulate over a period of time [15]. Durowoju et al. [19] showed that the geothermal spring can enrich surface soil with heavy metals, which could possibly lead to contamination, particularly where the geothermal spring water is used for irrigation and agricultural purposes. This makes the community vulnerable to the effects of trace elements composition emanating from the geothermal spring to human beings via food chain [20].

The accumulation of heavy metals, especially $\mathrm{As}, \mathrm{Cd}, \mathrm{Cr}, \mathrm{Cu}, \mathrm{Pb}, \mathrm{Hg}, \mathrm{Ni}$, $\mathrm{Se}$, and $\mathrm{Zn}$, is of concern in agricultural production systems due to the potential threat adversely affecting food quality (safety and marketability), crop growth (through phytotoxicity), or environmental health (soil flora/fauna and terrestrial animals) [21]. The aim of this study is therefore to investigate whether the trend of heavy metals concentrations from Siloam geothermal spring to the surface soil and vegetation potentially affects the environment and the health of the inhabitants of the area who depend on the geothermal spring, as their source of domestic water supply and agricultural purposes. This study also incorporates the seasonal variations of the heavy metals concentrations from geothermal spring water, surface soil and Mangifera indica and the ability of Mangifera indica to phytoremediate contaminated soils. Seasonal variation is important in showing the distribution and potential risks of heavy metals with time. The community depends on this geothermal spring as a reliable alternative source of water without a clear understanding of heavy metals concentrations and their bioaccumulation in the ecosystem. Therefore, this work will elucidate on the impacts of heavy metals from the geothermal spring on the surrounding soil and vegetation as well as phytoremediative ability of Mangifera indica to mitigate the potential health and environmental impacts.

\section{Experimental Section}

\subsection{Study Area}

Siloam village, which is the study area, geologically falls under the youngest formation of the Soutpansberg Group, which is the Sibasa Formation. Siloam geothermal spring is located at the $22^{\circ} 36^{\prime} 05.48^{\prime \prime} \mathrm{S}$ and $30^{\circ} 10^{\prime} 23.01^{\prime \prime} \mathrm{E}$ (Figure 1). It is dominated by basalt, which originated from the lava at the base of the formation. It is responsible for the more undulating topography to the south of the Soutpansberg [22]. There are dark-red shale and sandstones that are fine, thinly-bedded sandstones. There is an interlayer of tuff, ignimbrite, and chert and in places tuffaceous shale [23]. The various types of conglomerate are also available such as argillaceous and arenaceous types. The mudstone and siltstone of Delvis Gully member also exist [23]. Siloam village is characterized by fractured aquifers of sandstone where groundwater occurs. The Siloam spring is found in a private property at Siloam village. 


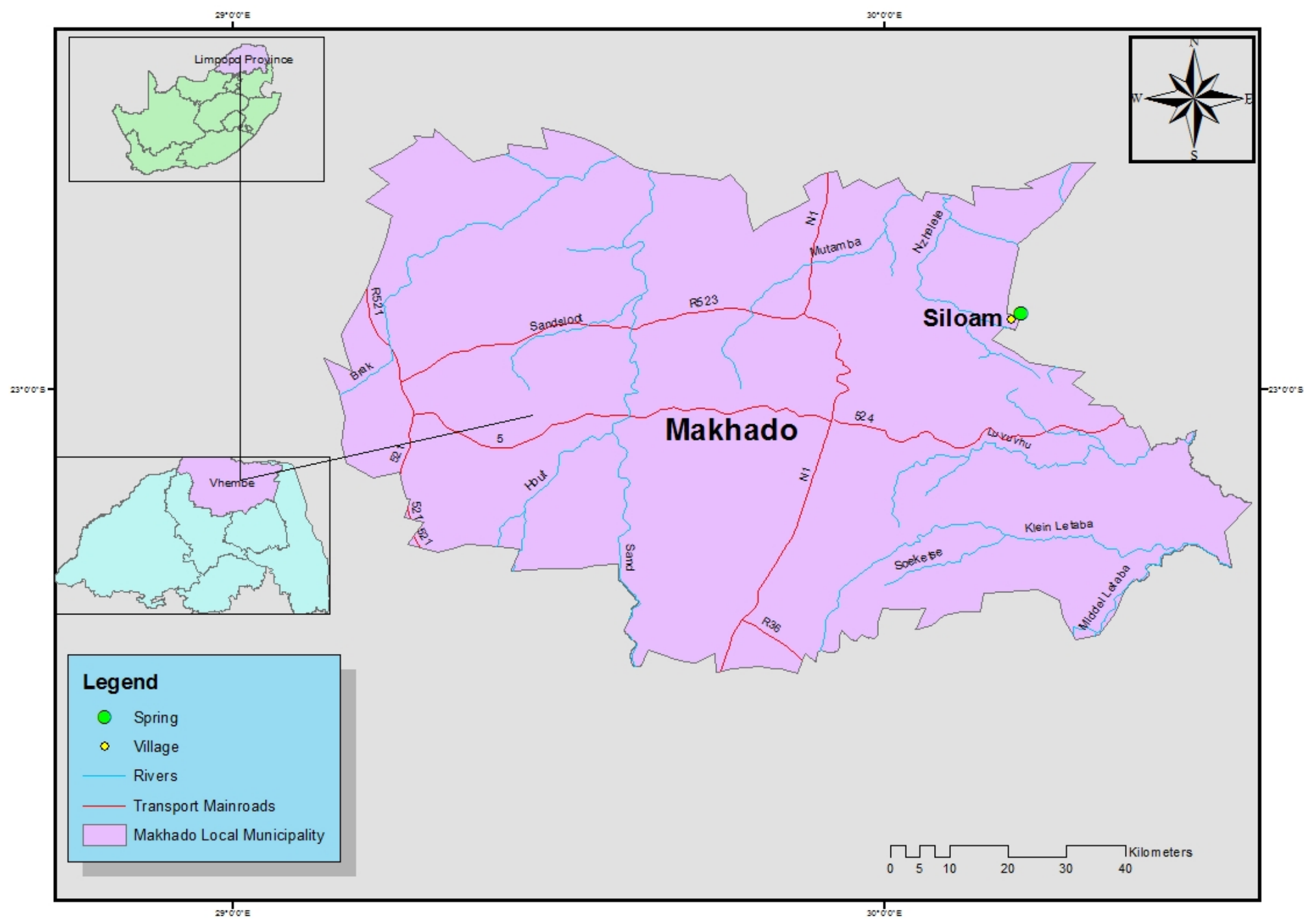

Figure 1. Map showing the geothermal spring at Siloam village, Limpopo, South Africa. 


\subsection{Sampling}

Sampling was undertaken during winter (May-July) and summer (October-December) seasons in 2014. The sampling was carried out once per month for three months in each season. The geothermal water samples were collected at the source (only outlet point) after rinsing the sample bottle with the spring water. Owing to the high temperature of water, cooling was allowed before adding two $\mathrm{mL}$ of concentrated nitric acid to the one litre of water sample and stored at low temperature (around $4{ }^{\circ} \mathrm{C}$ ) [24].

Simple random sampling procedure adopted by Pleysier [25] was followed for sampling soil. Surface soil was sampled from a depth of $0-15 \mathrm{~cm}$ in about $0-10 \mathrm{~m}$ distance around the geothermal spring. Three sampling points were identified around the geothermal spring close to the vegetation. A representative soil sample was obtained by mixing all the samples obtained and put inside a sampling bag, preferably polypropylene bag. The soil samples were oven dried by breaking down aggregates at $50{ }^{\circ} \mathrm{C}$ for $8 \mathrm{~h}$. The dried soil samples were grounded and sieved through $100 \mu \mathrm{m}$ sieve [26].

The bark and leaves from Mangifera indica were collected within the same conditions the soil was sampled and oven dried at $50{ }^{\circ} \mathrm{C}$ for $8 \mathrm{~h}$ before grinding [26]. The vegetation samples were handpicked and a representative sample was obtained by taking a number of sample units randomly and combining them to form a bulk sample. The vegetation was within $10 \mathrm{~m}$ from the geothermal springs. All the vegetation samples were collected in the polypropylene bag and transported to the laboratory before the sample pre-treatment. Mangifera indica was chosen because it is a plant species that grows around the geothermal spring at Siloam. The bark and leaf parts of the Mangifera indica were sampled owing to their ability to accumulate heavy metals from the soil [27].

\subsection{Experimental Procedure}

The experimental procedure is shown in Figure 2. The water samples were not digested because they were acidified during the sample pre-treatment [24]. Samples were filtered with $1 \mathrm{~mm}$ size filter and further diluted 10 times for ICP-MS analysis.

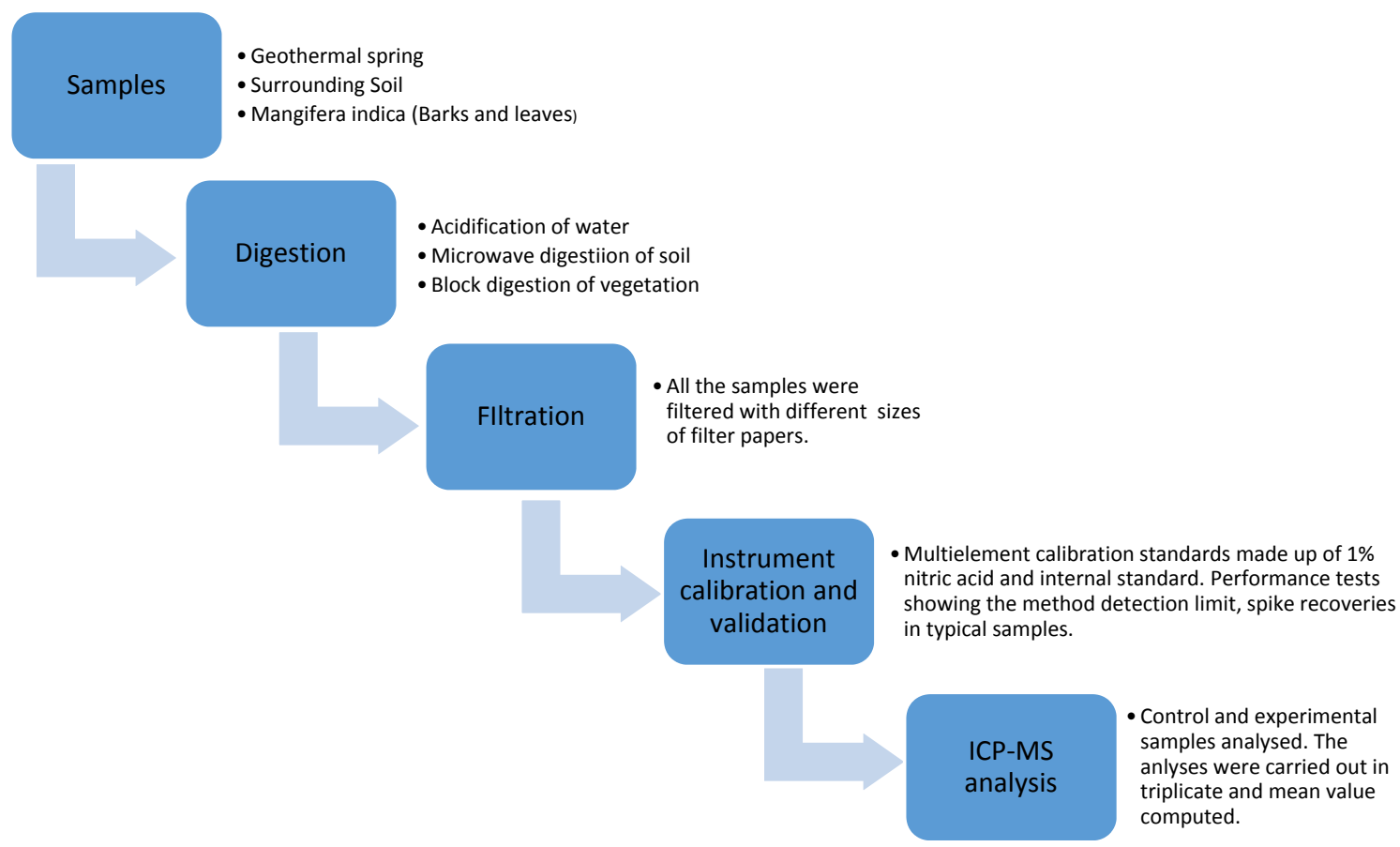

Figure 2. Schematic diagram of the experimental procedure. 
The soil samples were analysed by digesting using a microwave digestion system [26]. Approximately $1.0 \mathrm{~g}$ of pre-treated samples were digested with $9 \mathrm{~mL} \mathrm{HNO}_{3}$ and $1 \mathrm{~mL} \mathrm{H}_{2} \mathrm{O}_{2}$; the solution was allowed overnight and placed in the microwave for $30 \mathrm{~min}$. After cooling, it was diluted to $50 \mathrm{~mL}$ with distilled water and filtered with $15 \mathrm{~mm}$ size filter before ICP-MS analysis.

The vegetation samples (bark and leaves) were digested using Hot Block Method. $0.5 \mathrm{~g}$ ground root and leaves samples were weighed and $14 \mathrm{~mL}$ of $16 \mathrm{M} \mathrm{HNO}_{3}$ was added. The solution was allowed to stay overnight and was placed in the block digestion system at initial temperature of $80^{\circ} \mathrm{C}$ for $30 \mathrm{~min}$ and increased at intervals of $10^{\circ} \mathrm{C}$ up to $120^{\circ} \mathrm{C}$. Three to four drops of $\mathrm{H}_{2} \mathrm{O}_{2}$ were added and shaken for a few minutes, then allowed to cool for $20 \mathrm{~min}$. Then, it was made up to $100 \mathrm{~mL}$ with de-ionized water and filtered with $15 \mathrm{~mm}$ size filter before ICP-MS analysis.

\subsection{Quality Assurance/Quality Control}

Quality assurance/Quality control (QA/QC) was incorporated into geothermal spring water, soil and vegetation sampling to enhance sample integrity, increase the confidence of analytical data as reliable analytical information, and to prevent reporting wrong positive values caused by contamination. Field blank and splits were ensured for water sample; blank and splits for soil samples were rinsed and splits extracted for the vegetation samples. Control samples were taken to ensure that the anomalous concentrations are associated with identified potential source of the heavy metals. The water, soil and vegetation samples were taken three times per each season to ascertain the heavy metal behaviour per season. All the experimental analyses were done in triplicate to provide representative mean values.

The method detection limit (MDL) for each heavy metal was obtained by US EPA method 200.8 [28]. In order to validate the analytical methodology, recovery studies were performed. Known concentrations of the test analyte were added to the sample. The concentrations of both the spiked and unspiked samples were determined and percentage recovery was obtained. The validation test performed on the analytical methods employed gave reproducible results with acceptable recoveries. Recovery percentages were $95.8 \%$ for $\mathrm{Cr}, 94.6 \%$ for $\mathrm{Co}, 93.3 \%$ for $\mathrm{Ni}, 92.2 \%$ for $\mathrm{Cu}, 92.7 \%$ for $\mathrm{Zn}, 91.6 \%$ for As, $93.8 \%$ for $\mathrm{Cd}$, and $90.2 \%$ for $\mathrm{Pb}$.

\subsection{Statistical Analysis}

All values from chemical analyses were presented as mean values. Data obtained from the experiment were subjected to two-tailed test (Mann-Whitney $U$ test) using the Statistical Package for Social Science (SPSS version 22) to validate any significant differences between the two seasons. The data was also subjected to descriptive statistics to evaluate the mean and error bars at $90 \%$ confidence interval to show the variations. In all cases, $p<0.05$, was the accepted significance level.

\section{Results and Discussion}

The MDL for each heavy metal is $0.001 \mu \mathrm{g} / \mathrm{L}(\mathrm{Cr}), 0.002 \mu \mathrm{g} / \mathrm{L}(\mathrm{Co}), 0.002 \mu \mathrm{g} / \mathrm{L}(\mathrm{Ni}), 0.009 \mu \mathrm{g} / \mathrm{L}$ $(\mathrm{Cu}), 0.1 \mu \mathrm{g} / \mathrm{L}(\mathrm{Zn}), 0.03 \mu \mathrm{g} / \mathrm{L}(\mathrm{As}), 0.01 \mu \mathrm{g} / \mathrm{L}(\mathrm{Cd})$, and $0.0004 \mu \mathrm{g} / \mathrm{L}(\mathrm{Pb})$. Geothermal springs are usually mineralized to a greater or lesser extent depending on the characteristics of the geological formations associated with the circulating groundwater [29]. Heavy metals concentrations in water samples collected from Siloam geothermal springs and 1 borehole (non-geothermal source) are given in Table 1. The results show that the geothermal spring water was more mineralized especially with regard to $\mathrm{As}, \mathrm{Cd}$, and $\mathrm{Pb}$ levels in summer season compared to the borehole (non-geothermal source) serving as control. This could be attributed to rainfall which enhances more rock-water interaction at the deep aquifer. All the analyzed heavy metals in the geothermal spring water fall within WHO [30] and SABS [31] guidelines for drinking water except for $\mathrm{As}, \mathrm{Cd}$, and $\mathrm{Pb}$ values, which are high in the summer season. 
Table 1. Mean heavy metals concentrations in geothermal spring water, surface soil, and Mangifera indica (barks and leaves).

\begin{tabular}{|c|c|c|c|c|c|c|c|c|}
\hline Elements & $\mathrm{Cr}$ & Co & $\mathrm{Ni}$ & $\mathrm{Cu}$ & $\mathrm{Zn}$ & As & Cd & $\mathrm{Pb}$ \\
\hline \multicolumn{9}{|c|}{ Water analysis $(\mu \mathrm{g} / \mathrm{L})$} \\
\hline WHO;SABS & $50 ; 100$ & & $20 ; 150$ & $2000 ; 1000$ & $3000 ; 5000$ & $10 ; 10$ & & $10 ; 20$ \\
\hline Control W & $0.03 \pm 0.01$ & $0.16 \pm 0.06$ & $2.62 \pm 0.54$ & $0.21 \pm 0.06$ & $50.7 \pm 6.22$ & $0.09 \pm 0.06$ & $0.06 \pm 0.03$ & $0.09 \pm 0.03$ \\
\hline Control S & $0.03 \pm 0.03$ & $0.16 \pm 0.04$ & $2.64 \pm 0.51$ & $0.21 \pm 0.01$ & $58.7 \pm 1.84$ & $0.09 \pm 0.03$ & $0.1 \pm 0.01$ & $0.13 \pm 0.03$ \\
\hline Water W & $0.11 \pm 0.03$ & $0.02 \pm 0.00$ & $0.01 \pm 0.00$ & $0.06 \pm 0.03$ & $0.24 \pm 0.06$ & $0.63 \pm 0.10$ & $0.01 \pm 0.00$ & $0.12 \pm 0.03$ \\
\hline Water S & $0.33 \pm 0.10$ & $0.24 \pm 0.08$ & $0.18 \pm 0.03$ & $0.03 \pm 0.03$ & $0.13 \pm 0.04$ & $\mathbf{4 6 2 . 1 1} \pm 11.16$ & $211 \pm 12.73$ & $342 \pm 14.14$ \\
\hline \multicolumn{9}{|c|}{ Soil analysis $(\mathrm{mg} / \mathrm{Kg})$} \\
\hline DNHPD, 1991 & 80 & 20 & 50 & 100 & 185 & 2 & 2 & 56 \\
\hline Control W & $54.00 \pm 5.66$ & $19.10 \pm 2.12$ & $25.03 \pm 2.08$ & $70.46 \pm 2.83$ & $50.19 \pm 4.24$ & $1.39 \pm 0.28$ & $0.23 \pm 0.04$ & $21.40 \pm 1.41$ \\
\hline Control S & $58.46 \pm 1.66$ & $19.14 \pm 2.83$ & $25.08 \pm 6.96$ & $70.56 \pm 6.28$ & $50.23 \pm 6.75$ & $1.39 \pm 0.14$ & $0.25 \pm 0.01$ & $21.42 \pm 2.23$ \\
\hline Soil W & $65.12 \pm 2.83$ & $39.04 \pm 1.41$ & $59.33 \pm 5.19$ & $95.22 \pm 1.95$ & $174.51 \pm 7.06$ & $0.83 \pm 0.28$ & $0.17 \pm 0.04$ & $74.60 \pm 4.81$ \\
\hline Soil S & $\mathbf{9 2 . 0 6} \pm 1.41$ & $43.11 \pm 2.83$ & $58.19 \pm 4.24$ & $266.97 \pm 4.29$ & $236.05 \pm 5.59$ & $0.655 \pm 0.03$ & $0.11 \pm 0.03$ & $45.74 \pm 1.78$ \\
\hline \multicolumn{9}{|c|}{ Mangifera indica $(\mathrm{mg} / \mathrm{Kg})$} \\
\hline Control W & $8.09 \pm 1.21$ & $1.41 \pm 0.30$ & $33.06 \pm 2.06$ & $35.42 \pm 2.23$ & $120.73 \pm 6.04$ & $1.65 \pm 0.28$ & $0.02 \pm 0.01$ & $1.07 \pm 0.03$ \\
\hline Control S & $15.32 \pm 1.24$ & $3.26 \pm 0.91$ & $33.45 \pm 0.78$ & $46.12 \pm 2.66$ & $129.12 \pm 8.32$ & $2.14 \pm 0.23$ & $0.02 \pm 0.01$ & $2.01 \pm 0.08$ \\
\hline Bark W & $0.87 \pm 0.01$ & $0.34 \pm 0.03$ & $1.78 \pm 0.03$ & $2.60 \pm 0.28$ & $10.40 \pm 0.42$ & $0.03 \pm 0.00$ & $0.01 \pm 0.00$ & $0.14 \pm 0.03$ \\
\hline Bark S & $2.06 \pm 0.01$ & $0.48 \pm 0.03$ & $0.04 \pm 0.00$ & $7.32 \pm 0.03$ & $16.22 \pm 0.03$ & $0.37 \pm 0.03$ & $0.02 \pm 0.01$ & $0.01 \pm 0.00$ \\
\hline \multicolumn{9}{|c|}{ Mangifera indica $(\mathrm{mg} / \mathrm{Kg})$} \\
\hline Control W & $7.67 \pm 0.14$ & $3.01 \pm 0.28$ & $31.74 \pm 2.06$ & $24.04 \pm 1.41$ & $24.04 \pm 0.04$ & $0.34 \pm 0.06$ & $0.84 \pm 0.03$ & $1.34 \pm 0.03$ \\
\hline Control S & $10.28 \pm 1.94$ & $7.98 \pm 0.35$ & $32.10 \pm 2.69$ & $32.12 \pm 7.95$ & $46.87 \pm 3.30$ & $0.79 \pm 0.28$ & $1.23 \pm 0.10$ & $2.31 \pm 0.27$ \\
\hline Leaf W & $0.93 \pm 0.03$ & $0.08 \pm 0.14$ & $1.29 \pm 0.14$ & $4.09 \pm 1.41$ & $10.90 \pm 1.41$ & $0.04 \pm 0.01$ & $0.01 \pm 0.00$ & $0.11 \pm 0.02$ \\
\hline Leaf $S$ & $1.14 \pm 0.14$ & $0.14 \pm 0.03$ & $0.04 \pm 0.01$ & $128.11 \pm 0.61$ & $196.58 \pm 1.41$ & $0.35 \pm 0.07$ & $0.03 \pm 0.00$ & $2.94 \pm 0.06$ \\
\hline
\end{tabular}

$\mathrm{W}=$ winter, $\mathrm{S}$ = summer; Values in bold indicate exceedance of SABS [31]; WHO [30] and DNHPD [32] guideline values for drinking water and agricultural soil, respectively. 
There is seasonal variation in the heavy metal concentrations in the geothermal spring water (Figure 3). Heavy metals concentrations were higher in summer season compared to winter season except for $\mathrm{Cu}$ and $\mathrm{Zn}$. This could be attributed to high rainfall in summer, which enhances more dissolution of rock particles leading to more mineralization [33]. Elemental $\mathrm{Cu}$ and $\mathrm{Zn}$ are less reactive in water but due to the thermal property of the spring water, there is more reaction resulting in higher concentrations in winter compared to the summer season. The high concentrations of $\mathrm{As}, \mathrm{Cd}$, and $\mathrm{Pb}$ in summer pose potential negative health effects on the Siloam community since the spring serves as one of their sources of water. The spring water is used for cooking, peeling of chicken feathers, and other domestic purposes, in which the heavy metals are ingested into the body. There is a significant difference between the heavy metals concentrations in both seasons $(Z=-2.1035, p<0.05)$.

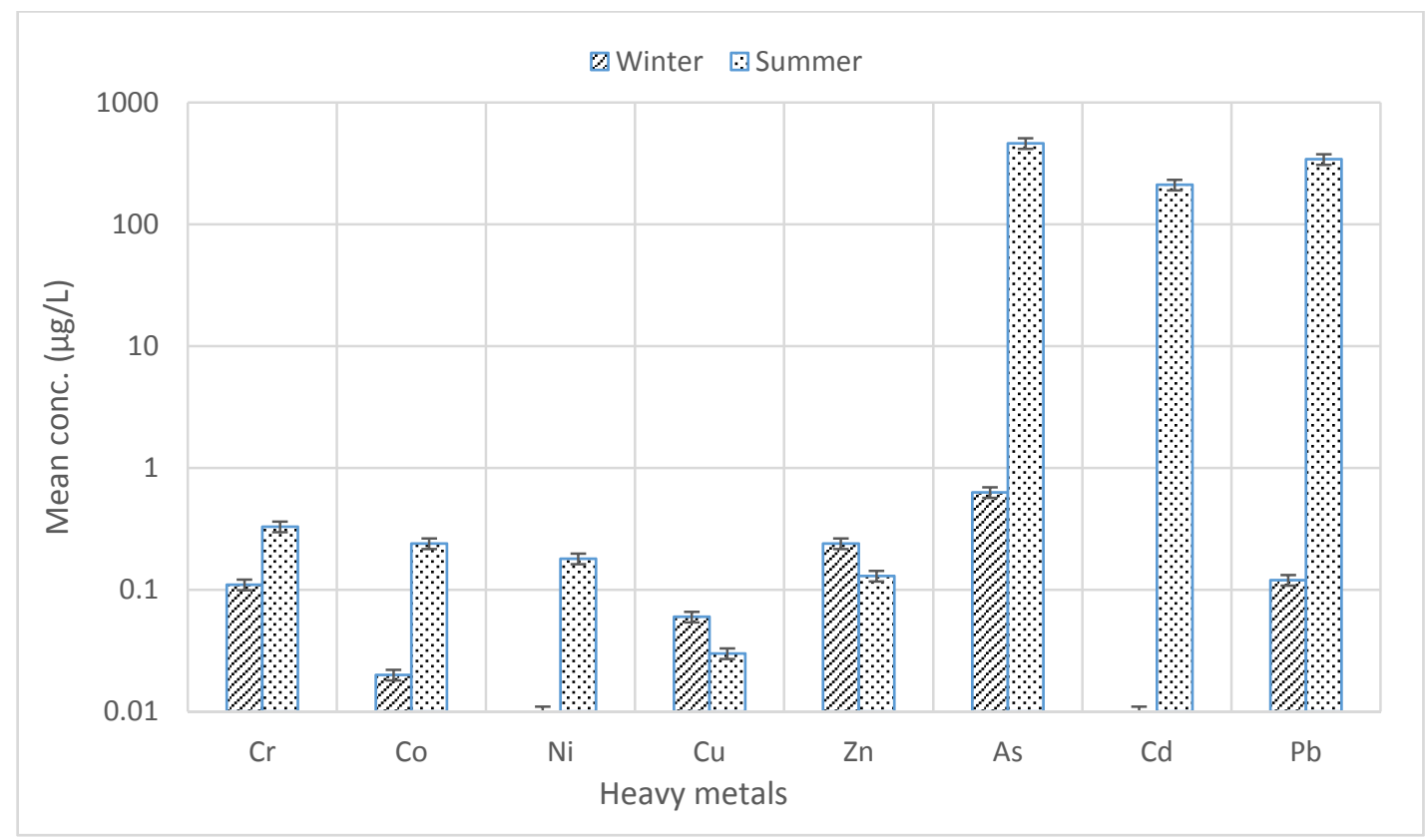

Figure 3. Seasonal variation of heavy metals in geothermal spring water.

Correlation analysis of mean concentrations of heavy metals in spring water and surrounding soil reflect the association between heavy metals and the similarity of their pollution sources. Heavy metal concentrations from the spring water were positively correlated to each other, which implies same source of formations (rock-water interaction). Table 2 shows significant correlations between the concentrations of $\mathrm{Cr}$ and the concentrations of $\mathrm{Co}, \mathrm{Ni}, \mathrm{Cu}$, and $\mathrm{Zn}$ (Same source) in the soil. The correlation coefficient was large and significant whereas As is significantly correlated to $\mathrm{Cd}$ and $\mathrm{Pb}$. The correlation analysis and factor analysis were complementary and two factors were obtained from the factor analysis on the concentrations of heavy metals in the soil (Table 3). Factor 1 represents $58.64 \%$ of the total variance with high loading of $\mathrm{Cr}, \mathrm{Co}, \mathrm{Ni}, \mathrm{Cu}$, and $\mathrm{Zn}$. This could be attributed to the soil pedogenesis and heavy metals from geothermal spring water whereas Factor 2 represents $38.67 \%$ of the total variance with high loading of $\mathrm{As}, \mathrm{Cd}$ and $\mathrm{Pb}$. This factor could be associated with rock-water interaction in the deep aquifers leading to high concentrations of these heavy metals $(\mathrm{As}, \mathrm{Cd}$, and $\mathrm{Pb})$ from the geothermal spring. Factor analysis on concentrations of heavy metals from geothermal spring water shows only one factor, which is attributed to rock-water interaction in the deep aquifers. 
Table 2. Correlation analysis and coefficients for the heavy metals in surrounding soil.

\begin{tabular}{ccccccccc}
\hline Elements & $\mathbf{C r}$ & $\mathbf{C o}$ & $\mathbf{N i}$ & $\mathbf{C u}$ & $\mathbf{Z n}$ & $\mathbf{A s}$ & $\mathbf{C d}$ & $\mathbf{P b}$ \\
\hline $\mathrm{Cr}$ & 1.00 & & & & & & & \\
$\mathrm{Co}$ & $0.99^{* *}$ & 1.00 & & & & & & \\
$\mathrm{Ni}$ & $0.98^{* *}$ & $0.99^{* *}$ & 1.00 & & & & & \\
$\mathrm{Cu}$ & $0.84^{* *}$ & $0.78^{*}$ & $0.75^{*}$ & 1.00 & & & & \\
$\mathrm{Zn}$ & $0.77^{*}$ & $0.76^{*}$ & $0.75^{*}$ & $0.93^{* *}$ & 1.00 & & & \\
$\mathrm{As}$ & -0.22 & -0.22 & -0.23 & -0.26 & -0.34 & 1.00 & & \\
$\mathrm{Cd}$ & -0.22 & -0.22 & -0.22 & -0.26 & -0.32 & $1.00^{* *}$ & 1.00 & \\
$\mathrm{~Pb}$ & -0.09 & -0.01 & 0.05 & -0.12 & -0.16 & $0.97^{* *}$ & $0.97^{* *}$ & 1.00 \\
\hline
\end{tabular}

** Correlation is significant at the 0.01 level (2-tailed); * Correlation is significant at the 0.05 level (2-tailed).

Table 3. Explaining the total variance of factor analysis from the surrounding soil.

\begin{tabular}{ccc}
\hline \multirow{2}{*}{ Elements } & \multicolumn{2}{c}{ Factor } \\
\cline { 2 - 3 } & $\mathbf{1}$ & $\mathbf{2}$ \\
\hline $\mathrm{Cr}$ & $\mathbf{0 . 9 7}$ & -0.26 \\
$\mathrm{Co}$ & $\mathbf{0 . 9 5}$ & -0.28 \\
$\mathrm{Ni}$ & $\mathbf{0 . 9 3}$ & -0.28 \\
$\mathrm{Cu}$ & $\mathbf{0 . 9 1}$ & -0.21 \\
$\mathrm{Zn}$ & $\mathbf{0 . 9 6}$ & -0.27 \\
$\mathrm{As}$ & -0.32 & $\mathbf{0 . 9 5}$ \\
$\mathrm{Cd}$ & -0.32 & $\mathbf{0 . 9 5}$ \\
$\mathrm{Pb}$ & -0.17 & $\mathbf{0 . 9 8}$ \\
\hline Total variance & $\mathbf{5 8 . 6 4}$ & $\mathbf{3 8 . 6 7}$ \\
\hline
\end{tabular}

Note: In bold are high positive scores $(\geqslant 0.50)$

Soils are important receptacles for heavy metals and they naturally contain trace levels of these elements. Heavy metals found in the surrounding soil to the geothermal spring were as a result of the geothermal spring water and the soil pedogenesis [19]. The geothermal spring water contaminates the surrounding soil with heavy metals absorbed as water flows or get utilized in the surroundings. The findings of the study were compared with South African guidelines for maximum permissible heavy metals concentrations in agricultural soils (Table 1). Heavy metals concentrations in soil during summer were higher in $\mathrm{Cr}, \mathrm{Co}, \mathrm{Ni}, \mathrm{Cu}, \mathrm{Zn}$, and $\mathrm{Pb}$, compared to South African maximum permissible limits for agricultural soils [32]. Though, only $\mathrm{Co}, \mathrm{Ni}$, and $\mathrm{Pb}$ had their concentrations in surface soil in winter exceeding the DNHPD [32] standards for agricultural soils, $\mathrm{Cr}, \mathrm{Cu}$, and $\mathrm{Zn}$ also had very significant concentrations in winter. These could be attributed to long term accumulation of heavy metals concentrations from the geothermal springs and high utilization of spring water on the soil, which ultimately leads to contamination. This study shows that the surrounding soils from the geothermal springs were contaminated with heavy metals, which enter the human body via the food chain. Similarly, the seasonal mean concentrations of the heavy metals were generally higher in summer compared to winter season in the surface soil (Figure 4). There were slight seasonal variations in the concentrations of the heavy metals in the surface soil having higher values for $\mathrm{Cr}, \mathrm{Co}, \mathrm{Cu}$, and $\mathrm{Zn}$ in summer and $\mathrm{Ni}, \mathrm{As}, \mathrm{Cd}$, and $\mathrm{Pb}$ in winter season. Statistically, there were no significant differences between the heavy metals concentrations in both seasons $(Z=0.053, p>0.05)$. 


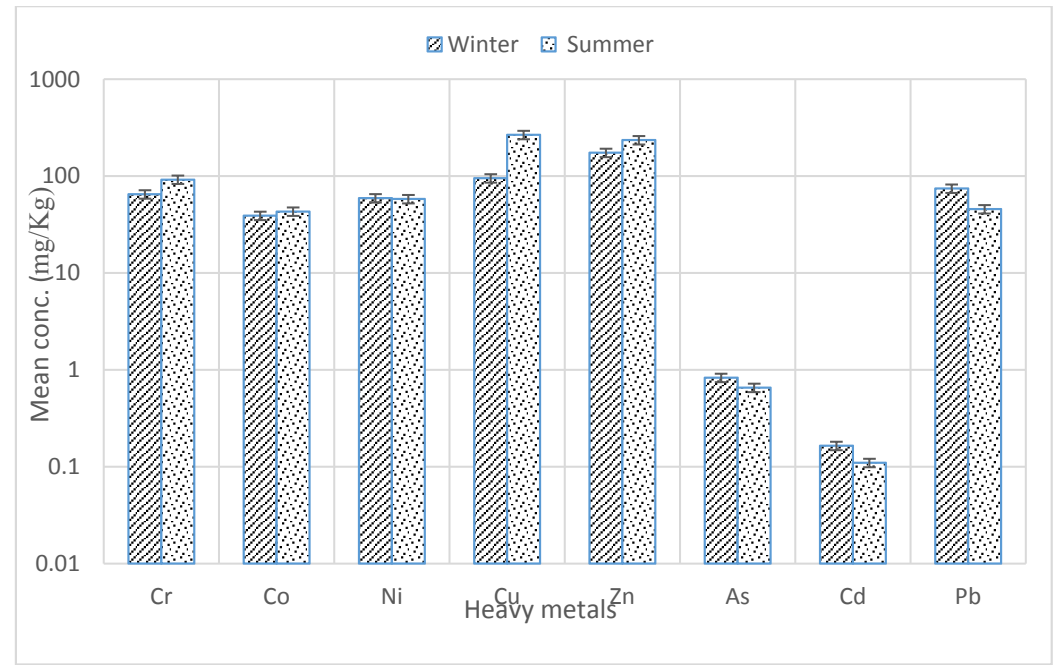

Figure 4. Seasonal variations of heavy metals concentrations in surrounding soil.

Vegetation growing on soils with high concentrations of heavy metals have a tendency of absorbing the heavy metals through its root system and transporting them to other parts of the plant; these include fruits. This study has shown that geothermal spring water contaminates the surrounding surface soil with heavy metals (Table 1). Since plants depend on soil for their nutrients, there is a high possibility of absorbing and transmitting these heavy metals. Heavy metal concentrations shown in Table 1 for the bark and leaf of Mangifera indica show that the control had higher concentrations compared to the samples, except for $\mathrm{Cu}, \mathrm{Zn}$, and $\mathrm{Pb}$ in the leaves in summer. This implies that Mangifera indica can have phytoremediative ability. The mean concentrations of the analyzed heavy metals reveal that surrounding Mangifera indica has lesser concentrations compared to the control except for the leaves in summer, despite the fact that the soil is contaminated. The bark of Mangifera indica shows less absorption of the heavy metals since it is part of the root system. Concentrations of heavy metals tend to be slightly higher in summer than winter (Figures 5 and 6) and this could be as a result of high rainfall, which aids more dissolution in summer season. There is no significant differences between heavy metals concentrations in the bark of Mangifera indica in both seasons ( $Z=0, p>0.05)$. This implies that there is slight seasonal variation (Figure 5 ) in the concentrations of the heavy metals but not statistically significant.

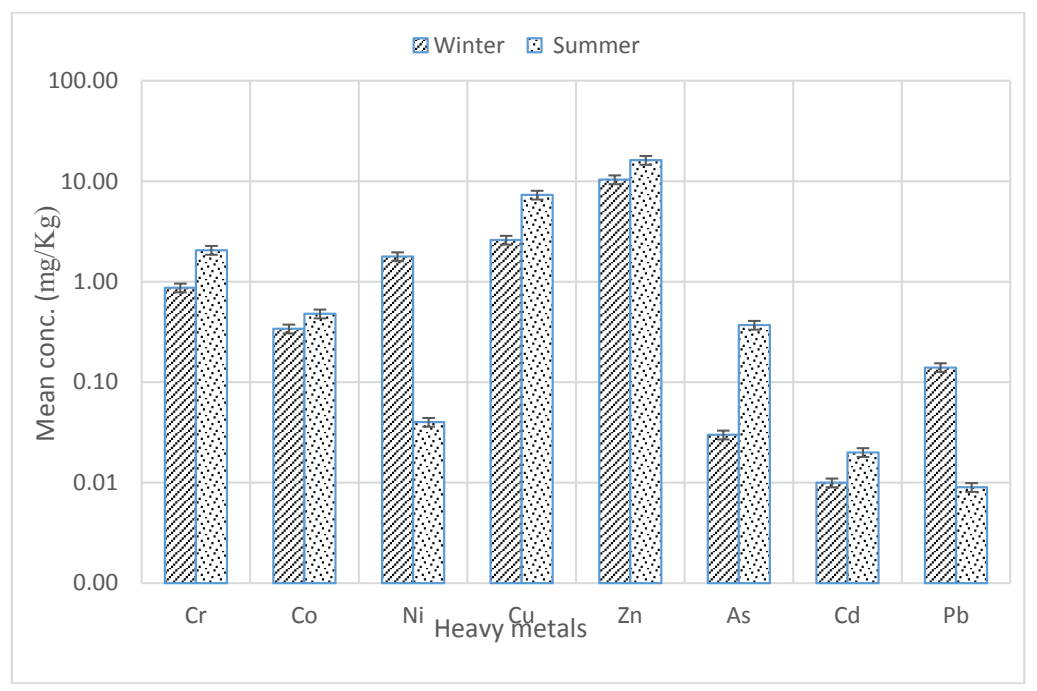

Figure 5. Seasonal variations of heavy metals concentrations in barks of Mangifera indica. 
The concentrations of heavy metals in leaves were higher in summer than in winter except for $\mathrm{Ni}$ (Figure 6). Similarly, the concentrations of heavy metals were higher in the barks in summer than in winter except for $\mathrm{Ni}$ and $\mathrm{Pb}$ (Figure 5). The concentrations of heavy metals were relatively higher in the leaves as compared to the barks. This implies that there were more elements in the leaves compared to the barks, which shows that there is rapid transpiration process from the root system to the leaves. There is fruit formation during summer, during which the absorbed trace elements will be utilized during the plant's metabolism for fruit formation. Hence, there is more transpiration in the leaf part of Mangifera indica from the root system, enriching the leaf parts more, compared to the bark parts [34].

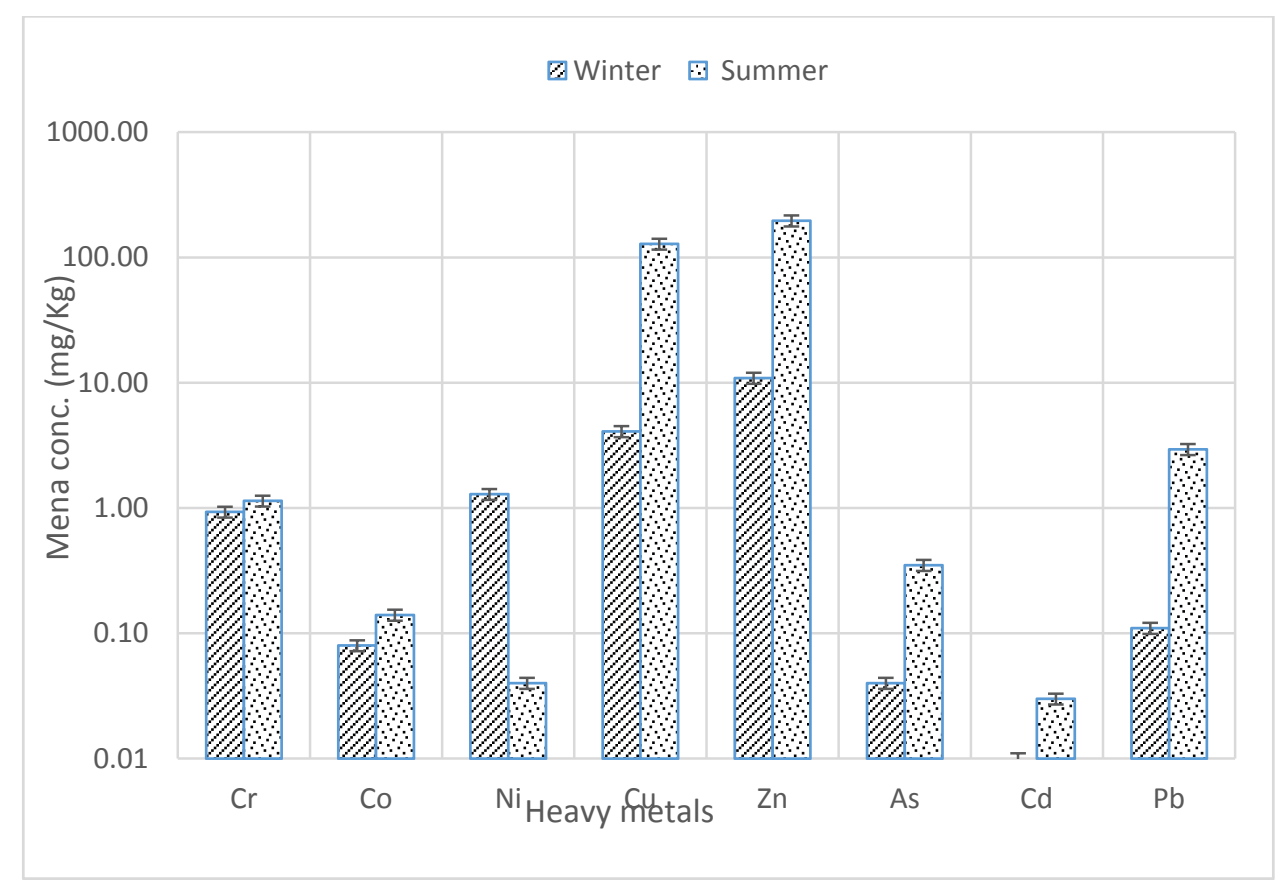

Figure 6. Seasonal variations of heavy metals concentrations in leaves of Mangifera indica.

There is no significant differences in the concentrations of the heavy metals from the leaves in both seasons $(Z=-0.524, p>0.05)$. This implies that the concentrations of the heavy metals in Mangifera indica vary with seasons but is not statistically significant. The summer season yields higher concentrations compared to the winter season. Generally, there are significant differences in the concentrations of heavy metals between the leaves and barks in both seasons $(p<0.05)$. This implies that the leaves have higher absorption rates and utilize their heavy metals more in the summer season (fruit formation) compared to the winter season (Figure 6).

\section{Conclusions}

Levels of $\mathrm{Cr}, \mathrm{Co}, \mathrm{Ni}, \mathrm{Cu}, \mathrm{Zn}, \mathrm{As}, \mathrm{Cd}$, and $\mathrm{Pb}$ in geothermal spring water, surrounding soil, and Mangifera indica (barks and leaves) at Siloam village have been determined in this study by ICP-MS after acidification (geothermal spring water), microwave acid digestion (soil), and block digestion methods (leaves and barks). The analytical results indicated that in both winter and summer seasons, some heavy metals concentrations were above the standard guidelines for drinking water and typical soil. This is a cause for concern as this can affect the environment and the health of the inhabitants of Siloam village, who depend on the geothermal spring as their source of drinking, domestic water, irrigation and other uses. Relatively, the heavy metals concentrations were higher in summer compared to winter seasons for geothermal spring water, surrounding soil and Mangifera indica and this could be attributed to high rainfall, which aids more mineralisation in summer. Heavy metal concentrations in Mangifera indica were low compared to the control samples except for $\mathrm{Cu}, \mathrm{Zn}$, and $\mathrm{Pb}$ in the leaves in 
summer. This could possibly be as a result of phytoremediative ability of Mangifera indica because the surrounding soil was contaminated with $\mathrm{Cr}, \mathrm{Co}, \mathrm{Ni}, \mathrm{Cu}, \mathrm{Zn}$, and $\mathrm{Pb}$ but their concentrations were low in Mangifera indica. This study has shown that Mangifera indica has the ability to remediate contaminated surrounding soil at Siloam geothermal spring. This study has proven that the geothermal spring has potential of enriching the surrounding soil with heavy metals, which is absorbed by surrounding vegetation. Owing to phytoremediating ability of Mangifera indica in the surrounding contaminated soil, the heavy metals concentrations were reduced compared to concentrations in the soil especially in summer season. Additionally, Mangifera indica shows high clean up efficiency for $\mathrm{Cu}, \mathrm{Zn}$, and $\mathrm{Pb}$ in summer compared to winter. Therefore, further studies should be conducted on the efficiency of Mangifera indica for the clean-up of contaminated soil. The environmental significance of these findings is that hydromorphic dispersion trains of heavy metals from the geothermal spring water to their surrounding vegetation (Mangifera indica) via soil will enhance effective management of soil quality in the area.

Acknowledgments: The authors would like to thank National Research Foundation, Pretoria, South Africa and University of Venda for funding and various forms of support.

Author Contributions: Sample preparation and analyses were done by Olatunde S. Durowoju, John. O. Odiyo and Georges-Ivo E. Ekosse contributed immensely to the writing and discussion of the final manuscript. All the authors approved the final manuscript for publication.

Conflicts of Interest: The authors declare no conflict of interest.

\section{References}

1. Durowoju, O.; Odiyo, J.; Ekosse, G. Hydrogeochemical setting of geothermal springs in Limpopo Province, South Africa- A Review. Res. J. Chem. Environ. 2015, 19, 77-88.

2. Olivier, J.; Venter, J.S.; Jonker, C.Z. Thermal and Chemical Characteristics of Thermal Springs in the Northern Part of the Limpopo Province, South Africa. Water SA 2011, 34, 163-174.

3. Taylor, J.; Phillips, F. Balneology or Taking Waters. 2007. Available online: http:/ /www.selfgrowth.com (accessed on 21 October 2014).

4. Kent, L.E. Thermal waters of the Union of South Africa and South West Africa. Trans. Geol. Soc. WS. Afr. $1949,52,231-264$.

5. Witcher, J.C. Masson Radium Springs Farm; GHC BULLETIN; Southwest Technology Institute, New Mexico State University: Las Cruces, NM, USA, 2002.

6. Odiyo, J.O.; Makungo, R. Fluoride concentrations in groundwater and impact on human health in Siolam Village, Limpopo Province, South Africa. Water SA 2012, 38, 731-736. [CrossRef]

7. Manda, L.; Suzuki, K.T. Arsenic around the world: A review. Talanta 2012, 58, 201-235. [CrossRef]

8. Romero, L.; Alomso, H.; Campano, P.; Fanfani, L.; Cidu, R.; Dadea, C.; Keegan, T.; Thornton, I.; Farago, M. Arsenic enrichment in waters and sediments of the Rio Loa (Second Region, Chile). Appl. Geochem. 2003, 18, 1399-1416. [CrossRef]

9. Churchill, R.K.; Clinkenbeard, J.P. Perspectives on mercury contributions to watersheds from historic mercury mines and non-mine mercury sources: Examples from the sulphur creek mining district. In Proceedings of the Cordilleran Section-101st Annual Meeting, Piedmont, Italy, 29 April-1 May 2005.

10. Ifegwu, C.; Anyakora, C. Screen for eight heavy metals in groundwater samples from highly industrialized area of Lagos, Nigeria. Afri. J. Pharm. Sci. Pharm. 2012, 3, 1-16.

11. Hutton, M.; Symon, C. The Quantities of Cadmium, Lead, Mercury and Arsenic Entering the U.K. Environment from Human Activities. Sci. Total Environ. 1986, 57, 129-150. [CrossRef]

12. Battarbee, R.; Anderson, N.; Appleby, P.; Flower, R.G.; Fritz, S.; Haworth, E.; Higgit, S.; Jones, V.; Kreiser, A.; Munro, M.A.; et al. Lake Acidification in the United Kingdom; ENSIS: London, UK, 1988.

13. Nriagu, J.O.; Pacyna, J. Quantitative Assessment of Worldwide Contamination of Air, Water and Soil by Trace Metals. Nature 1988, 333, 134-139. [CrossRef] [PubMed]

14. Garbarino, J.R.; Hayes, H.; Roth, D.; Antweider, R.; Brinton, T.I.; Taylor, H. Contaminants in the Mississipi River; U.S. Geological Survey Circular: Rapid City, SD, USA, 1995.

15. Hawkes, J.S. Heavy Metals. J. Chem. Educ. 1997, 74, 1374. [CrossRef] 
16. Yahaya, M.I.; Mohammad, S.; Abdullahi, B.K. Seasonal variations of heavy metal concentration in Abattoir dumping site soil in Nigeria. J. Appl. Sci. Environ. Manag. 2009, 13, 9-13. [CrossRef]

17. Gune, M.S.; Alpaslan, M.; Inal, A. Plant Growth and Fertilizer; Ankara university of Agriculture: Ankara, Turkey, 2004.

18. Trueby, P. Impact of Heavy Metals on Forest Trees from Mining Areas. In Proceedings of the International Conference on Mining and the Environment, Sudbury, ON, Canada, 25-28 May 2003.

19. Durowoju, O.; Odiyo, J.; Ekosse, G. Horizontal status of trace elements from Siloam and Tshipise geothermal springs to their surface soil. Water SA 2015. under review.

20. Aggett, P.J. Trace element deficiencies in man. In Role of Trace Elements for Health Promotion and Disease Prevention; Sandström, B., Walter, P., Eds.; Karger: Basel, Switzerland, 1998; Volume 54, pp. 18-28.

21. McLaughlin, M.J.; Hamon, R.E.; McLaren, R.G.; Speir, T.W.; Rogers, S.L. Review: A bioavailability-based rationale for controlling metal and metalloid contamination of agricultural land in Australia and New Zealand. Aust. J. Soil Res. 2000, 38, 1037-1086. [CrossRef]

22. Brandl, G. The geology of the Pietersburg area. In Explanation Sheet, Geological Survey of South Africa; Geological Maps: Pietersburg, South Africa, 1986; Volume 2328, p. 43.

23. Mundalamo, H.R. Investigation of Water Quality in Nzhelele Valley, Limpopo Province, South Africa. Honours Mini-Dissertation, University of Venda, Thohoyandou, South Africa, 2003.

24. United State Environmental Protection Agency (USEPA). Guideline for Water Reuse; EPA: Washington, DC, USA, 2004.

25. Pleysier, L.J. Soil sampling and sample preparation. Available online: http://www.cglrc.cgiar.org/iita/ soilSampling/ (accessed on 3 January 2016).

26. SR ISO 11466. Soil Quality-Extraction of Trace Elements Soluble in Aqua Regia; International Organization for Standardization: Geneva, Switzerland, 1999.

27. Pyle, S.M.; Nocerino, J.M.; Deming, S.N.; Palasota, J.A.; Palasota, J.M.; Miller, E.L.; Hillman, D.C.; Kuharic, C.A.; Cole, W.H.; Fitzpatrick, P.M.; et al. Comparison of AAS, ICP-AES, PSA, and XRF in determining Lead and Cadmium in Soil. Environ. Sci. Tech. 1996, 30, 204-213. [CrossRef]

28. United State Environmental Protection Agency (USEPA). (1994) Method 200.8. Determination of Trace Elements in Waters and Wastes by ICP, Revision 5.4. Available online: http:/ / www.epa.gov/sam/pdfs/ EPA-200.8.pdf (accessed on 14 December 2014).

29. Todd, D.K. Groundwater Hydrology, 2nd ed.; Wiley: New York, NY, USA, 1980; pp. 535-552.

30. World Health Organisation (WHO). Bottled Drinking Water. 2000. Available online: http://www.who.int/ mediacentre/factsheets/fs256/en/print.html (accessed on 19 August 2014).

31. South African Bureau of Standards (SABS). Class 1 Potable Water Standards; SABS 241:1999; South African Bureau of Standards: Pretoria, South Africa, 1999.

32. Department of National Health and Population Development (DNHPD). Guide: Permissible Utilisation and Disposal of Sewage Sludge; Ref: A11/2/5/4; DNHPD: Pretoria, South Africa, 1991.

33. Chouba, L.; Kraiem, M.; Njimi, W.; Tissaoui, C.H.; Thompson, J.R.; Flower, R.J. Seasonal variation of heavy metals ( $\mathrm{Cd}, \mathrm{Pb}$ and $\mathrm{Hg}$ ) in sediments and in mullet, Mugil cephalus (Mugilidae), from the Ghar El Melh Lagoon (Tunisia). Waters Bull. 2007, 4, 45-52.

34. McGrath, S.P.; Chang, A.C.; Page, A.L.; Wilter, E. Land application of sewage sludge: Scientific perspective of heavy metal loading limits in Europe and United States. Environ. Rev. 1994, 2, 108-118. [CrossRef]

(C) 2016 by the authors; licensee MDPI, Basel, Switzerland. This article is an open access article distributed under the terms and conditions of the Creative Commons by Attribution (CC-BY) license (http://creativecommons.org/licenses/by/4.0/). 